2. WeAVer, R.H. \& VirTue, R.W. Blood Oxygenation as affected by tidal volume and tension of nitrous oxide-oxygen inhaled at one mile altitude. Anesthesiology 16:57(1955).

3. HiLl, D.W. \& LowE, H.J. Comparison of concentration of halothane in closed and semiclosed circuit during controlled respiration. Anesthesiology 23: 291 (1962).

4. Mostert, J.W., Goldberg, I.S., Lanzel, E.F. \& Lowe, H.J. Das geschlossere System. Anaesthetist 26: 495 (1977).

5. Herscher, E. \& Yeakel, A.E. Nitrous oxideoxygen anesthesia: the waste and its cost. Anesth. Rev. 4: 29 (1977).

6. Virtue, R.W., Escobar, A. \& Modell, J. Nitrous Oxide Levels in Operating Room Air with Various Gas Flows. Canad. Anaesth. Soc. J. 26: 313-318, July 1979.

\section{EPIDURAL TEST DOSE}

\section{DEAR SIR}

We read with interest the recent article by Fargas-Babjak, et al., "The Efficacy of Bupivacaine 0.75 Per Cent as an Epidural Test Dose".' Although the authors encountered no complications in their two cases presented, we feel that the use of a three $\mathrm{ml}$ test dose of 0.75 per cent bupivacaine may be ill-advised.

If the recommended test dose were to be injected into the subarachnoid space, we are concerned that there may be a significantly large number of patients with high or total spinal anaesthetics. Support for this concern comes from the in vitro and in vivo potency of bupivacaine relative to other anaesthetics reported by Covino ${ }^{2}$ (among others), and recent experience with the use of the drug for subarachnoid block reported by Moore. ${ }^{3}$ The former suggests bupivacaine to be equally as potent as tetracaine and the latter reports sensory blocks as high as the second thoracic dermatome after $12 \mathrm{mg}$ hyperbaric injections. The fact that the patients of Fargas-Babjak, et al. suffered no ill effects from test doses as high as $\mathbf{2 3} \mathbf{~ m g}$ is hardly reassuring.

A second consideration which has us concerned is the possibility of intravenous injection of the advocated test dose. We wonder if some subjects might not display significant central nervous system or cardiovascular morbidity. Tahir ${ }^{3}$ reported a case of light-headedness after using only $20 \mathrm{mg}$ of bupivacaine in divided doses. As there is some suggestion that bupivacaine gives less forewarning of CNS toxicity than other local anaesthetic agents ${ }^{2}$ and may cause more long lasting cardiotoxicity, ${ }^{4}$ it would appear not to be the local anaesthetic of choice when there is a risk of intravenous injection. A secondary issue is that of the foetal effects of intravenous injection of bupivacaine. Although significant foetal blood levels of bupivacaine are unlikely to occur, and there is an excellent record with bupivacaine for use during labor and delivery, 5,6 it is significant that the half life of the drug in foetal blood has been quoted as three and one-half hours.?

We should like to counter-propose that an effective test dose for epidural anaesthesia in parturients would be $2 \mathrm{ml}$ of 2 -chloroprocaine 2 or 3 per cent. Although this drug may be hypobaric or isobaric at body temperature, the quantity which would be injected subarachnoid is not excessive and duration of such a block should be as short as that lidocaine, or shorter. Furthermore, serum half life of the drug in the blood of parturients with normal plasma cholinesterase levels has been measured at 21 seconds and in that of the term foetus 43 seconds. ${ }^{7}$ Hence, of the two drugs most commonly used in obstetrical practice, it would seem that 2-choloroprocaine would be the safest choice for initiation of epidural anaesthesia. ${ }^{6}$ Not only should an intravenous injection with the test or subsequent dose produce less significant maternal or foetal morbidity but also an intrathecal injection should result in a block of lesser magnitude and shorter duration.

Fred J. Spielman, M.D.

Chief Resident;

Charles B. Watson, M.D.

Assistant Professor,

Department of Anesthesiology, North Carolina Memorial Hospital, Chapel Hill, N.C. 27514, U.S.A.

\section{REFERENCES}

1. Fargas-Babjak, A., McChesney, J. \& Morison, D.H. The efficacy of bupivacaine 0.75 percent as an epidural test dose. Canad. Anaesth. Soc. J. 2\%: $500(1980)$

2. Covino, B.G. Local Anesthetic Agents, Lecture Notes \& Annual Anesthesiology Review Course; Society of Air Force Anesthesiologists 114: 1-57, June 12-16 (1978).

3. Tahir, A.H., Adriani, J. \& Naraghi, M. Acule systemic toxicity from bupivacaine during epidural anesthesia in obstetric patients. South. Med. J. 68: 1377 (1975).

4. Albright, G.A. Cardiac arrest following regional anesthesia with etidocaine or bupivacaine. Anesthesiology 51:285 (1979). 
5. DATTA, A. Anesthesiology for caesarian section. Anesthesiology 53: 142 (1980).

o. Villa, E.A., Marx, G.F. Chloroprocainebupivacaine sequence for obstetric extractual analgesia. Canad. Anaesth. Soc. J. 22: 76 (1975).

7. Algright, G. Anesthesia in Obstetrics: Maternal, Fetal, and Neonatal Aspects. Menlo Park: Addison-Wesley (1978)

\section{EPIDURAL TEST DOSE}

We would like to respond to the comments made by F.J. Spielman and C.B. Watson. While $3 \mathrm{ml}$ of bupivacaine $0.75 \%$ was used as a test dose in one of the cases reported, we did not recommend a specific volume to be used as a test dose. Moore's recent report ${ }^{1}$ on the use of bupivacaine in spinal anaesthesia gives the mean height of block achieved after $1.6 \mathrm{ml}$ of bupivacaine $0.75 \%$ as T4 \pm 2 . Thus, the amount of bupivacaine $0.75 \%$ to be used as a test dose should probably be in the range of $1.5-2.0 \mathrm{ml}(11.25-15 \mathrm{mg})$.

We did not consider the importance of a test dose in demonstrating the possibility of an intravascular injection. Another recent report by Moore $^{2}$ discussed the effects of $3 \mathrm{ml}$ of bupivacaine $0.75 \% \pm$ epinephrine when injected intravenously. Bupivacaine without epinephrine only caused signs of slight toxicity in five out of forty patients but with epinephrine it consistently caused tachycardia and 50 per cent complained of transient palpitation. Thus, to detect intravenous injection, a local anaesthetic containing epinephrine would appear preferable.

The suggestion that 2-chloroprocaine would be preferable as a test dose is not helpful in Canada, as this drug is not regularly available. Also, $2 \mathrm{ml}$ of 2 or 3 per cent 2-chloroprocaine might not give a very obvious spinal block. Covino, et al.$^{3}$ recommend $4-5 \mathrm{ml}$ of 2 per cent or $3 \mathrm{ml}$ of 3 per cent 2-chloroprocaine in their editorial, which also cautioned against the use of larger volumes of this drug when injected intrathecally because of reports of prolonged sensory and motor deficits.

D.H. Morrison, M.B., Ch.B., F.R.C.P.(C),

Associate Professor,

Department of Anaesthesia,

McMaster University,

Hamilton, Ontario.

\section{REFERENCES}

1. MOORE, D.C. Spinal Anaesthesia: Bupivacaine Compared with Tetracaine. Anes. Analg. 59: 743-750 (1980).
2. Moore, D.C. The Recovery Ingredients of a Test Dose Prior to Epidural or Caudal Injection. A.S.A. Abstracts. Anes. 53: 3, S214 (1980).

3. Covino, B.J., MarX, G.F., Finster, M. \& ZsigMOND, E.K. Prolonged Sensory/Motor Deficits Following Inadvertent Spinal Anesthesia. Anes. Analg. 59: 399-400 (1980).

\section{SEIZURE ACTIVITY ASSOCIATED WITH ENFLURANE}

SIR,

$\mathrm{Ng}^{1}$ is to be congratulated for bringing the attention of the anaesthesia community to the problem of seizure activity in the immediate postoperative period, associated with enflurane. Kruczek, et al. ${ }^{2}$ recently reported a generalized tonic/clonic seizure after an enflurane anaesthetic in a healthy young female with no personal or family history of seizures. Arterial blood gases immediately after the seizure revealed normocarbia. Electroencephalographic examination twelve days postoperatively showed focal irregularities in the posterior right temperal lobe with the EEG returning to normal after forty days.

Both of these patients received thiopentone for induction, which has been shown to exacerbate electroencephalographic seizure activity during light enflurane anaesthesia. ${ }^{3}$ These two case reports and that reported by $\mathrm{Ohm}$, et al. ${ }^{4}$ suggest that the development of delayed seizure activity may be due to enflurane or one of its metabolites producing an irritable focus that manifests itself only after the administration of the anaesthetic.

Steven Wolf, M.D.,

Department of Anesthesiology,

School of Medicine,

The University of North Carolina at Chapel Hill,

Chapel Hill, N.C. 27514, U.S.A.

\section{REFERENCES}

1. NG, A.T. Prolonged myoclonic contractions after enflurance anesthesia - A case report. Canad. Anaesth. Soc. J. 27: 502 (1980).

2. Kruczek, M., Albin, M.S., Wolf, S. \& BerToN , J.M. Post operative seizure activity following enflurance anesthesia. Anesthesiology 53:175, (1980).

3. Furgang, F.A. \& Sohn, J.J. The effect of thiopentone on enflurane induced cortical seizures. Brit. J. Anaesth. 49: 127 (1977).

4. OhM, W.W., Cullen, B., Amory, D.W. \& KenNEDY, R.D. Delayed seizure activity following enflurane anesthesia. Anesthesiology 42: 367 (1975). 